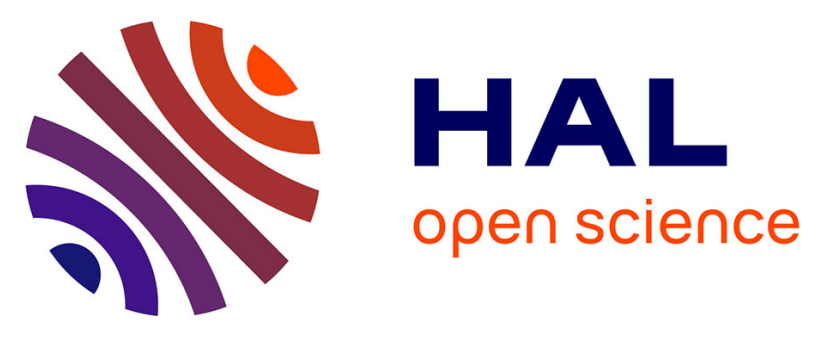

\title{
Prevalence of Pathogenic Variants of FAN1 in More Than 5000 Patients Assessed for Genetic Predisposition to Colorectal, Breast, Ovarian, or Other Cancers
} Alice Fievet, Emmanuelle Mouret-Fourme, Chrystelle Colas, Antoine de Pauw, Dominique Stoppa-Lyonnet, Bruno Buecher

\section{To cite this version:}

Alice Fievet, Emmanuelle Mouret-Fourme, Chrystelle Colas, Antoine de Pauw, Dominique StoppaLyonnet, et al.. Prevalence of Pathogenic Variants of FAN1 in More Than 5000 Patients Assessed for Genetic Predisposition to Colorectal, Breast, Ovarian, or Other Cancers. Gastroenterology, 2019, 156, pp.1919 - 1920. 10.1053/j.gastro.2019.01.003 . hal-03486819

\section{HAL Id: hal-03486819 https://hal.science/hal-03486819}

Submitted on 20 Dec 2021

HAL is a multi-disciplinary open access archive for the deposit and dissemination of scientific research documents, whether they are published or not. The documents may come from teaching and research institutions in France or abroad, or from public or private research centers.
L'archive ouverte pluridisciplinaire HAL, est destinée au dépôt et à la diffusion de documents scientifiques de niveau recherche, publiés ou non, émanant des établissements d'enseignement et de recherche français ou étrangers, des laboratoires publics ou privés.

\section{(ㄷ)(1) $\$$}

Distributed under a Creative Commons Attribution - NonCommerciall 4.0 International 


\section{Prevalence of pathogenic variants of FAN1 among more than 5000 consecutive} patients referred to one genetic clinic for suspected hereditary predisposition to colorectal, breast/ovarian or other cancers.

Alice Fievet ${ }^{1,2}$, Emmanuelle Mouret-Fourme ${ }^{1}$, Chrystelle Colas ${ }^{1}$, Antoine de Pauw ${ }^{1}$, Dominique Stoppa-Lyonnet ${ }^{1,3}$, Bruno Buecher ${ }^{1}$

1 - Institut Curie, PSL Research University, Department of Tumor Biology, F-75005, Paris, France

2 - Institut Curie, PSL Research University, INSERM U 830, F-75005, Paris, France

3 - Paris Descartes University, Sorbonne Paris Cité, F-75005, Paris, France

Short title: FAN1: a colorectal cancer susceptibility gene?

\section{Corresponding author:}

Buecher B, Institut Curie, PSL Research University, Department of Tumor Biology, 26, rue d'Ulm, F-75005, Paris, France

Tel: 00331443246 94; Fax: 0033153102648 ;

Mail: bruno.buecher@curie.fr

\section{Author contributions to manuscript:}

I, the designated Corresponding Author, certify that myself and each of my coauthors have contributed to manuscript as follows:

- Alice Fievet: study concept and design; technical support; analysis and interpretation of data; drafting of the manuscript; critical revision of the manuscript; study supervision

- Emmanuelle Mouret-Fourme: study concept and design; acquisition of data; analysis and interpretation of data; statistical analysis; critical revision of the manuscript.

- Chrystelle Colas : acquisition of data; critical revision of the manuscript.

- Antoine de Pauw : acquisition of data ; critical revision of the manuscript.

- Dominique Stoppa-Lyonnet : acquisition of data; analysis and interpretation of data; critical revision of the manuscript; study supervision

- Bruno Buecher : study concept and design; acquisition of data; analysis and interpretation of data; drafting of the manuscript; study supervision

The authors wish to thank Graham Smith for editorial assistance

\section{Conflict of interest statement:}

The authors declare no conflicts of interest

\section{Abbreviations:}

$\mathrm{CRC}=$ Colorectal cancer; FAN1 $=$ FANCD2/FANCl-Associated Nuclease $1 ; \mathrm{KIN}=$ karyomegalic interstitial nephropathy; NGS = new generation sequencing; NCCN = National Comprehensive Cancer Network; pMMR = mismatch repair-proficient; WES $=$ whole exome sequencing 
Introduction

Despite significant advances in the molecular diagnosis of hereditary colorectal cancer (CRC) during the past decades, numerous clinical situations suggestive of major genetic predisposition remain unexplained. In 2015, Segui et al. identified FAN-1 (FANCD2/FANCI-Associated Nuclease 1) gene as a potential major gene of predisposition to colorectal polyps/cancer (1). Indeed, whole exome sequencing (WES) led to the identification of a heterozygous nonsense truncating alteration of this gene in three affected relatives from a Spanish family with unexplained aggregation of mismatch repair-proficient (pMMR) CRC. Another nonsense variant of FAN1 and three missense variants, two of which being predicted as damaging by in silico algorithms, were further identified in 177 unrelated pMMR Amsterdam-positive Spanish families. Despite these data, Broderick et al. considered that the contribution of FAN1 in hereditary CRC was doubtful as evidence of co-segregation was weak with a non-significant non parametric linkage segregation score at $1.05(p=0.125)$ using all five families reported by Segui et al. and as no other alterations of FAN1 were identified on WES in five colorectal tumors arising in patients with either truncating or predicted damaging missense variation of this gene (2). Moreover, the authors performed WES in 863 familial CRC cases of European ancestry and in 1604 controls with no history of malignancy. They found no significant increase in the burden of FAN1 mutations in cases versus controls.

Methods

In order to further explore the contribution of FAN1 in the genetic predisposition to colorectal polyps/cancer, we assessed and compared the prevalence of pathogenic variants of $F A N 1$ in consecutive patients who were referred to our cancer genetic clinic between May 2015 and November 2017 because their personal and/or familial 
history was suggestive of a genetic predisposition to $\mathrm{CRC}$, breast or breast/ovarian cancer or other cancers/conditions. These patients met the French national genetic testing criteria that are very similar to those recommended by the NCCN (htpps://www.nccn.org).

Molecular analysis consisted in screening for pathogenic variants a panel of 56 genes using new generation sequencing (NGS). The panel includes FAN1 as our laboratory is involved in the molecular diagnosis of karyomegalic interstitial nephropathy (KIN) due to bi-allelic pathogenic variants of FAN1. Bioinformatic analysis of the NGS data was restricted to a panel of genes associated with the clinically suspected predisposition. FAN1 analysis was secondarily performed for the purposes of the study in patients who agreed to participate.

Results

FAN1 analysis was performed in a total of 5136 patients with a clinically suspected genetic predisposition to CRC (Group 1; $n=436$ ), breast or breast/ovarian cancer (Group 2; $n=3991$ ), or other cancers/conditions (Group 3; $n=709$ ). A mono-allelic pathogenic variant (nonsense and frameshift indel) of FAN1 was identified in 18 patients (0.35\%) in the entire series: 2 in Group 1; 14 in Group 2, and 2 in Group 3 corresponding to a frequency of heterozygotes of $0.46 \%, 0.35 \%$ and $0.28 \%$ respectively (Table 1). The frequency of heterozygotes in patients from Group 1 was not significantly different from that of Groups 2 or 3 (Fisher exact test, $p$-value $=0.7$ and 0.6 respectively), or from the expected frequency in the general population assessed in the 1000 Genomes and in the gnomAD v2.1 populations (Fisher exact test, $\mathrm{p}$-value $=0.3$ and 0.1 respectively).

One of the two patients in Group 1 with a pathogenic variant of FAN1 was a male with multiple hamartomatous polyps, and the other was a female diagnosed with 
endometrial adenocarcinoma at 53 years of age. No CRC was reported in the relatives of either patient. Moreover, no CRC was reported in the first/second degree relatives of the 16 index cases in Groups 2 or 3 with a pathogenic variation of FAN1. Discussion

The results of our study argue against the implication of pathogenic variants of FAN1 in unexplained cases of suspected genetic predisposition to colorectal polyps/cancer. Three other observations reinforce this conclusion: no CRC was declared in the close blood relatives of four index cases with $\mathrm{KIN}$ and bi-allelic germline mutation of FAN1 identified in our laboratory, nor in patients with some neurodevelopmental disabilities associated the $15 q 13.3$ microdeletion that encompasses FAN1 (3); the prevalence of pathogenic variants of FAN1 identified from exome data of 1449 colorectal adenocarcinomas available in cBioPortal (http://www.bioportal.org) is not significantly different from that reported in the gnomAD database (Fisher exact test, $p$-value=1). Based on these results and on previously published data, the French Groupe Génétique et Cancer decided not to include FAN1 in the recently designed consensus panel of genes that French genetic counseling centers should offer to all patients with a clinically suspected genetic predisposition to colorectal polyps/cancers.

\section{References}

1 - Segui N, et al. Gastroenterology 2015; 149: 563-566.

2 - Broderick P, et al. Gastroenterology 2017; 152: 75-77.

3 - Lowther C, et al. Genet Med 2015; 17:149-157 
Table 1: Pathogenic variants of FAN1 identified in the three groups of patients included in the entire series

\begin{tabular}{|c|c|c|c|c|c|}
\hline \multirow[t]{2}{*}{ cDNA change } & \multirow[t]{2}{*}{ Putative AA change } & \multirow[t]{2}{*}{ Type } & \multicolumn{3}{|c|}{ Number of patients } \\
\hline & & & $\begin{array}{l}\text { Group } 1 \\
(n=436)\end{array}$ & $\begin{array}{c}\text { Group } 2 \\
(n=3991)\end{array}$ & $\begin{array}{l}\text { Group } 3 \\
(n=709)\end{array}$ \\
\hline c.31_34del & p.(Lys11Glyfs*45) & frameshift deletion & & 1 & \\
\hline c.32_35del & p.(Lys11Serfs*45) & frameshift deletion & & 1 & \\
\hline c. $53 \mathrm{C}>\mathrm{A}$ & p.(Ser18*) & nonsense & & 1 & \\
\hline c.560_561del & p.(Thr187Serfs*3) & frameshift deletion & & 1 & \\
\hline c. $773 \mathrm{C}>\mathrm{G}$ & p.(Ser258*) & nonsense & & 1 & \\
\hline c.922_923del & p.(Val308Cysfs*5) & frameshift deletion & & 1 & 1 \\
\hline c.959del & p.(Glu320Glyfs*28) & frameshift deletion & 1 & & \\
\hline c.966dup & p.(Ser323llefs*3) & frameshift insertion & & 1 & \\
\hline c.1397_1398del & p. $($ Ser466*) & frameshift deletion & & 1 & \\
\hline c. $1606 C>T$ & p.(Arg536*) & nonsense & & 2 & \\
\hline c.2036_2037del & p.(Arg679Thrfs*5) & frameshift deletion & & 1 & \\
\hline c. $2116 C>T$ & p.(Arg706*) & nonsense & & 1 & \\
\hline c. $2128 \mathrm{C}>\mathrm{T}$ & p.(Arg710*) & nonsense & & 2 & \\
\hline c.2616del & p.(Asp873Thrfs*17) & frameshift deletion & 1 & & \\
\hline c. $2854 C>T$ & p.(Arg952*) & nonsense & & & 1 \\
\hline
\end{tabular}

cDNA: complementary DNA; AA: amino acid;

Group1: patients with suspected genetic predisposition to colorectal polyps/cancer.

Group 2: patients with suspected genetic predisposition to breast or breast/ovarian cancer.

Group 3: patients with suspected genetic predisposition to other cancers/conditions. 